\title{
Dietary inflammatory index and risk of upper aerodigestivearch Paper cancer in Japanese adults
}

\author{
Makiko Abe ${ }^{1,2,3}$, Nitin Shivappa 4,5,6, Hidemi Ito ${ }^{3,7}$, Isao Oze ${ }^{3}$, Tetsuya Abe ${ }^{8}$, Yasuhiro \\ Shimizu ${ }^{8}$, Yasuhisa Hasegawa ${ }^{9}$, Chikako Kiyohara ${ }^{1}$, Masatoshi Nomura ${ }^{10}$, Yoshihiro \\ Ogawa $^{2,11}$, James R. Hebert ${ }^{4,5,6}$ and Keitaro Matsuo ${ }^{3,7}$ \\ ${ }^{1}$ Department of Preventive Medicine, Kyushu University Faculty of Medical Sciences, Fukuoka, 812-8582, Japan \\ ${ }^{2}$ Department of Medicine and Bioregulatory Science, Graduate School of Medical Science, Kyushu University, Fukuoka, $812-$ \\ 8582, Japan \\ ${ }^{3}$ Division of Molecular and Clinical Epidemiology, Aichi Cancer Center Research Institute, Nagoya, 464-8681, Japan \\ ${ }^{4}$ Cancer Prevention and Control Program, University of South Carolina, Columbia, SC, 29208, USA \\ ${ }^{5}$ Department of Epidemiology and Biostatistics, Arnold School of Public Health, University of South Carolina, Columbia, SC, \\ 29208, USA \\ ${ }^{6}$ Connecting Health Innovations LLC, Columbia, SC, 29201, USA \\ ${ }^{7}$ Department of Epidemiology, Nagoya University Graduate School of Medicine, Nagoya, 466-8550, Japan \\ ${ }^{8}$ Department of Gastrointestinal Surgery, Aichi Cancer Center Hospital, Nagoya, 464-8681, Japan \\ ${ }^{9}$ Department of Head and Neck Surgery, Aichi Cancer Center Hospital, Nagoya, 464-8681, Japan \\ ${ }^{10}$ Department of Endocrinology and Metabolism, Kurume University School of Medicine, Kurume, 830-0011, Japan \\ ${ }^{11}$ Department of Molecular and Cellular Metabolism, Graduate School of Medical and Dental Sciences, Tokyo Medical and \\ Dental University, Tokyo, 113-8510, Japan
}

Correspondence to: Keitaro Matsuo, email: kmatsuo@aichi-cc.jp

Keywords: upper aerodigestive tract cancer; dietary inflammatory index; Japanese adults; persistent infection; case-control study

Received: November 26, $2017 \quad$ Accepted: April 13, $2018 \quad$ Published: May 08, 2018

Copyright: Abe et al. This is an open-access article distributed under the terms of the Creative Commons Attribution License 3.0 (CC BY 3.0), which permits unrestricted use, distribution, and reproduction in any medium, provided the original author and source are credited.

\section{ABSTRACT}

Background: The inflammatory potential of diet that has been shown to be associated with cancer risk. We examined the association between dietary inflammatory potential as measured by the dietary inflammatory index (DII ${ }^{\circledR}$ ) and risk of upper aerodigestive tract cancers in a Japanese case-control study.

Results: A positive association was observed between increasing DII scores and overall upper aerodigestive tract cancers, and across anatomic subsites. For upper aerodigestive tract cancers, the $\mathrm{OR}_{\mathrm{Q} 4 \mathrm{vs} 1}=1.73$ (95\% CI: 1.37-2.20); head and neck cancer, the $O R_{Q 4 v s Q 1}$ was 1.92 (95\% CI: 1.42-2.59); and for esophageal cancer, the $O R_{Q 4 v s Q 1}$ was1.71 (95\% CI: 1.54-1.90). Risks for hypopharyngeal and nasopharyngeal cancers were greatly elevated: $\left(O R_{\mathrm{Q} 4 \mathrm{vs} 1}=4.05\right.$ (95\% CI: 1.24-13.25) for hypopharyngeal cancer and $O R_{Q 4 v s 1}=4.99(95 \% \mathrm{CI}: 1.14-21.79)$ for nasopharyngeal cancer.

Conclusion: A more pro-inflammatory diet was associated with an elevated risk of upper aerodigestive tract cancers after accounting for important confounders. All anatomic subsites, except larynx, showed the consistently elevated risk with increasing DII score. Those subsites with known etiological associations with persistent infection showed the largest elevation in risk. These results warrant further evaluation in future studies.

Materials and Methods: This is a case-control study of 1,028 cases and 3,081 age- and sex-matched non-cancer controls recruited at Aichi Cancer Center. DII 
scores were computed based on estimates of macro- and micro-nutrients from a self-administered food frequency questionnaire. Scores were further categorized into quartiles (based on the distribution in controls). Conditional logistic regression models were fit to estimate odds ratio (OR) and $95 \%$ confidence intervals (CIs) adjusted for smoking, ethanol consumption, alcohol flushing, number of teeth, and occupation group.

\section{INTRODUCTION}

Upper aerodigestive tract cancers (UATC), encompassing the oral cavity, pharynx, larynx, salivary glands and esophagus, represent a significant cancer burden; collectively ranking fourth for cancer incidence and second for cancer mortality worldwide [1]. Smoking and excessive alcohol drinking are the two prominent risk factors for UATC [2-6]. In addition, a probable role of dietary exposure has been reported [7-9]; with non-starchy vegetables, and fruits having a protective role, and excess drinking, intake of red meat, and processed meat having a carcinogenic role [10]. Current evidence also indicates that diet plays a role in regulating inflammatory processes [11] by modulating the levels of inflammatory cytokines such as c-reactive protein (CRP), interleukin (IL)-6 and tumor necrosis factor (TNF)- $\alpha$ [12-14]. These components are associated with insulin resistance, adiposity, metabolic syndrome, and cardiovascular disease, and they have been shown to increase UATC risk by promoting proliferation, angiogenesis, and other mechanisms of carcinogenesis [15-24].

The literature-derived dietary inflammatory index $\left(\mathrm{DII}^{\mathbb{\circledR}}\right)$ was developed to measure the inflammatory potential of diet in relation to six inflammatory markers [25], including CRP [14], and IL-6 [26]. The DII has been associated with various neoplasms including esophageal [27], laryngeal [28], pharyngeal [29], colorectal [30], prostate [31], pancreatic [32], endometrial [33], and hepatocellular cancers [34]. Most DII research has been conducted primarily in European and European-American populations [35, 36]. In contrast, among Asians, including Japanese, epidemiologic evidence about the association between inflammatory potential of diet and cancer risk is sparse. Therefore, we investigated the association between inflammatory potential of dietary intake and UATC risk with in relation to DII scores among Japanese adults.

Our objective in this study was to examine whether more pro-inflammatory diets, as measured by DII, are associated with a higher risk of UATC and if there is an interaction between DII scores and potential effect modifiers.

\section{RESULTS}

Table 1 presents baseline characteristics of the cases and controls. Smoking, alcohol consumption, flushing phenotype, number of teeth, and occupation group were statistically significantly different between cases and controls in all UATC analysis. These differences also were observed in both head and neck cancer and esophagus cancers when analyzed separately. Smoking and alcohol consumption were more prevalent among cases compared with controls, and there were more blue-collar workers than white collar workers among cases. Absence of flushing after drinking and fewer teeth were more prevalent in cases. In further analyses, these variables were considered confounders.

Table 2 presents the distribution of characteristics across quartiles of DII. DII scores, which ranged from -4.31 (most anti-inflammatory) to +2.02 (most proinflammatory). We observed a statistically significant association between DII quartiles and smoking, alcohol and occupational group, but not flushing phenotype and number of teeth. Participants with higher DII scores tended to be male, younger, heavier smokers or drinkers, and blue-collar workers, compared to subjects with lower DII scores. Supplementary Table 2 presents the distribution of macro-and micro-nutrients and major food groups across DII quartiles among controls. All the nutrients showed statistically significant associations acorss DII quartiles. Carbohydrate showed a positive association with DII scores, while the others showed negative correlation. Food groups such as meat, fish, seafoods other than fish, greenyellow vegetables, other vegetables, fruits and soy also had statistically significant associations with DII quartiles and showed negative correlation with DII scores.

Table 3 shows the association between DII scores and risk for all UATC, and separately for head and neck, and esophageal cancer. A more pro-inflammatory diet was associated with an increased risk of UATC $\left(\mathrm{OR}_{\mathrm{O} 4 \mathrm{sSO} 1}\right.$ : 1.96; 95\% CI: $1.58-2.43 ; P$-trend $<0.001)$. This finding was essentially unchanged after adjusting for potential confounders $\left(\mathrm{OR}_{\mathrm{Q} 4 \mathrm{vs} Q 1}: 1.73,1.37-2.20 ; \quad P\right.$-trend < $0.001)$. Similarly, an inflammatory diet was associated with increased risk of head and neck cancer even after adjustment of confounders $\left(\mathrm{OR}_{\mathrm{Q} 4 \mathrm{vs} 1}: 1.92 ; 1.42-2.59\right.$; $P$-trend $<0.001)$. Adjusted $\mathrm{OR}_{\mathrm{Q} 4 \mathrm{vs} Q 1}$ remained significant for esophageal cancer $(1.71 ; 1.54-1.90)$; however, a linear trend was attenuated compared with UATC overall ( $P$-trend 0.07$)$. Table 4 shows results according to subsite in head and neck cancer. Among these, all but laryngeal cancers produced results consistent with overall UATC. Notably, nasopharyngeal cancer and hypopharyngeal cancer showed strong positive associations, even in second and third quartiles, compared with the lowest quartile. 
Table 1: Baseline characteristics of study subjects

\begin{tabular}{|c|c|c|c|c|c|c|c|c|c|c|c|}
\hline & \multicolumn{3}{|c|}{ Head and neck + Esophagus } & \multicolumn{5}{|c|}{ Head and neck } & \multicolumn{3}{|c|}{ Esophagus } \\
\hline & Case $(\%)$ & Control (\%) & $P$ value & & Case $(\%)$ & Control (\%) & $P$ value & & Case $(\%)$ & Control (\%) & $P$ value \\
\hline $\begin{array}{l}\text { All } \\
\text { male + female) }\end{array}$ & 1028 & 3081 & 0.83 & $\begin{array}{c}\text { All } \\
(\text { male }+ \text { female })\end{array}$ & 595 & 1,785 & 0.87 & $\begin{array}{c}\text { All } \\
(\text { male }+ \text { female })\end{array}$ & 433 & 1,296 & 0.89 \\
\hline male & $826(80.4)$ & $2,466(80.0)$ & & male & $450(75.6)$ & $1,344(75.3)$ & & male & $376(86.8)$ & $1,122(86.6)$ & \\
\hline female & $202(19.7)$ & $615(20.0)$ & & female & $145(24.4)$ & $441(24.7)$ & & female & $57(13.2)$ & $174(13.4)$ & \\
\hline Age (mean, SD) & $(60,10.9)$ & $(60,10.8)$ & 0.73 & Age (mean, SD) & $(60,10.9)$ & $(60,10.8)$ & 0.99 & Age (mean, SD) & $(60,10.9)$ & $(60,10.8)$ & 0.62 \\
\hline$<40$ & $56(5.5)$ & $171(5.6)$ & & $<40$ & $53(8.9)$ & $164(9.2)$ & & $<40$ & $3(0.7)$ & $7(0.5)$ & \\
\hline $40-49$ & $89(8.7)$ & $276(9.0)$ & & $40-49$ & $69(11.6)$ & $209(11.7)$ & & $40-49$ & $20(4.6)$ & $67(5.2)$ & \\
\hline $50-59$ & $306(29.8)$ & 907 (29.4) & & $50-59$ & $173(29.1)$ & $514(28.8)$ & & $50-59$ & $133(30.7)$ & $393(30.3)$ & \\
\hline $60-69$ & $364(35.4)$ & $1,144(37.1)$ & & $60-69$ & $184(30.9)$ & $565(31.7)$ & & $60-69$ & $180(41.6)$ & $579(44.7)$ & \\
\hline$\geq 70$ & $213(20.7)$ & $583(18.9)$ & & $\geq 70$ & $116(19.5)$ & $333(18.7)$ & & $\geq 70$ & $97(22.4)$ & $250(19.3)$ & \\
\hline Smoking & & & $<0.001$ & Smoking & & & $<0.001$ & Smoking & & & $<0.001$ \\
\hline Non & $201(19.6)$ & $1,135(36.8)$ & & Non & $152(25.6)$ & $697(39.1)$ & & Non & 49 (11.3) & $438(33.8)$ & \\
\hline Low-Modarate & $122(11.9)$ & $548(17.8)$ & & Low-Modarate & $84(14.1)$ & $345(19.3)$ & & Low-Modarate & $38(8.8)$ & $203(15.7)$ & \\
\hline High-Moderate & $276(26.9)$ & $636(20.6)$ & & High-Moderate & $144(24.2)$ & 344 (19.3) & & High-Moderate & $132(30.5)$ & $292(22.5)$ & \\
\hline Heavy & $413(40.2)$ & $730(23.7)$ & & Heavy & $204(34.3)$ & 385 (21.6) & & Heavy & $209(48.3)$ & 345 (26.6) & \\
\hline Unknown & $16(1.6)$ & $32(1.0)$ & & Unknown & $11(1.9)$ & $14(0.8)$ & & Unknown & $5(1.2)$ & $18(1.4)$ & \\
\hline $\begin{array}{l}\text { Alcohol } \\
\text { consumption }\end{array}$ & & & $<0.001$ & $\begin{array}{c}\text { Alcohol } \\
\text { consumption }\end{array}$ & & & $<0.001$ & $\begin{array}{c}\text { Alcohol } \\
\text { consumption }\end{array}$ & & & \\
\hline Non & $199(19.4)$ & $1,019(33.1)$ & & Non & $159(26.7)$ & $638(35.7)$ & & Non & $40(9.2)$ & $381(29.4)$ & \\
\hline Moderate & $176(17.1)$ & $848(27.5)$ & & Moderate & $121(20.3)$ & 475 (26.6) & & Moderate & $55(12.7)$ & $373(28.8)$ & \\
\hline $1-2$ go $\times 5 /$ week & $229(22.3)$ & $711(23.1)$ & & $1-2$ go $\times 5 /$ week & $123(20.7)$ & $392(22.0)$ & & $1-2$ go $\times 5 /$ week & $106(24.5)$ & 319 (24.6) & \\
\hline$>1-2$ go $\times 5 /$ week & $401(39.0)$ & $467(15.2)$ & & $>1-2$ go $\times 5 /$ week & $175(29.4)$ & $264(14.8)$ & & $>1-2$ go $\times 5 /$ week & $226(52.2)$ & $203(15.7)$ & \\
\hline Unknown & $23(2.2)$ & $36(1.2)$ & & Unknown & $17(2.9)$ & $16(0.9)$ & & Unknown & $6(1.4)$ & $20(1.5)$ & \\
\hline $\begin{array}{l}\text { Flushing } \\
\text { phenotype }\end{array}$ & & & $<0.001$ & $\begin{array}{l}\text { Flushing } \\
\text { phenotype }\end{array}$ & & & $<0.001$ & $\begin{array}{l}\text { Flushing } \\
\text { phenotype }\end{array}$ & & & \\
\hline Yes & $443(43.1)$ & $1,555(59.5)$ & & Yes & $263(44.2)$ & $900(50.4)$ & & Yes & $180(41.6)$ & $655(50.5)$ & \\
\hline No & $544(52.9)$ & $1,455(47.2)$ & & No & $302(50.8)$ & $843(47.2)$ & & No & $242(55.9)$ & $612(47.2)$ & \\
\hline Unknown & $41(4.0)$ & $71(2.3)$ & & Unknown & $30(5.0)$ & $42(2.4)$ & & Unknown & $11(2.5)$ & $29(2.2)$ & \\
\hline Teeth & & & $<0.001$ & Teeth & & & $<0.001$ & Teeth & & & $<0.001$ \\
\hline 0 & $79(7.7)$ & $121(3.9)$ & & 0 & $43(7.2)$ & $78(4.4)$ & & 0 & $79(7.7)$ & $121(3.9)$ & \\
\hline $1-8$ & $199(19.4)$ & $374(12.1)$ & & $1-8$ & $111(18.7)$ & $193(10.8)$ & & $1-8$ & $199(19.4)$ & $374(12.1)$ & \\
\hline $9-20$ & $309(30.1)$ & $879(28.5)$ & & $9-20$ & $168(28.2)$ & $499(28.0)$ & & $9-20$ & $309(30.1)$ & $879(28.5)$ & \\
\hline$\geq 21$ & $427(41.5)$ & $1,673(54.3)$ & & $\geq 21$ & $264(44.4)$ & $991(55.5)$ & & $\geq 21$ & $427(41.5)$ & $1,673(54.3)$ & \\
\hline Unknown & $14(1.4)$ & $34(1.1)$ & & Unknown & $9(1.5)$ & $24(1.3)$ & & Unknown & $14(1.4)$ & $34(1.1)$ & \\
\hline $\begin{array}{l}\text { Occupation } \\
\text { group }\end{array}$ & & & $<0.001$ & $\begin{array}{l}\text { Occupation } \\
\text { group }\end{array}$ & & & $<0.001$ & $\begin{array}{c}\text { Occupation } \\
\text { group }\end{array}$ & & & $<0.001$ \\
\hline Blue collar & $381(37.1)$ & 841 (27.3) & & Blue collar & $221(37.1)$ & $512(28.7)$ & & Blue collar & $160(37.0)$ & $329(25.4)$ & \\
\hline White collar & $217(21.1)$ & 917 (29.8) & & White collar & $131(22.0)$ & $529(29.6)$ & & White collar & $86(19.9)$ & 388 (29.9) & \\
\hline Other & 417 (40.6) & $1,272(41.3)$ & & Other & $235(39.5)$ & $719(40.3)$ & & Other & $182(42.0)$ & $553(42.7)$ & \\
\hline Unknown & $13(1.3)$ & $51(1.7)$ & & Unknown & $8(1.3)$ & $25(1.4)$ & & Unknown & $5(1.2)$ & $26(2.0)$ & \\
\hline Subsite & & & 1.00 & Subsite & & & & Subsite & & & \\
\hline \multicolumn{12}{|l|}{$\begin{array}{l}\text { Head and neck } \\
\text { cancer }\end{array}$} \\
\hline Oral cavity & $255(24.8)$ & $762(24.7)$ & & & & & & & & & \\
\hline Nasopharynx & $50(4.9)$ & $153(5.0)$ & & & & & & & & & \\
\hline Oropharynx & $72(7.0)$ & $214(7.0)$ & & & & & & & & & \\
\hline Hypopharynx & $80(7.8)$ & $240(7.8)$ & & & & & & & & & \\
\hline Larynx & $92(9.0)$ & $275(8.9)$ & & & & & & & & & \\
\hline Salivary gland & $23(2.2)$ & $72(2.3)$ & & & & & & & & & \\
\hline Other HNC & $23(2.2)$ & $69(2.2)$ & & & & & & & & & \\
\hline Esophagus & $433(42.1)$ & $1,296(42.1)$ & & & & & & & & & \\
\hline
\end{tabular}

Table 5 shows the adjusted ORs of UATC according to strata of selected confounders: age, sex, smoking, alcohol consumption, flushing phenotype, number of teeth, occupation group and their interactions. Although there is apparent variability in the impact of the association according to strata, positive associations between DII 
Table 2: DII distribution according to confounders among controls

\begin{tabular}{|c|c|c|c|c|c|}
\hline \multirow[t]{2}{*}{ Controls } & \multicolumn{5}{|c|}{ DII quartiles (\%) } \\
\hline & $1(-4.31--1.00)$ & $2(-1.00-0.11)$ & $3(0.11-0.58)$ & $4(0.58-2.02)$ & $P$ value \\
\hline Sex & & & & & $<0.001$ \\
\hline Male & $538(21.8)$ & $607(24.6)$ & $628(25.5)$ & $693(28.1)$ & \\
\hline Female & $233(37.9)$ & $163(26.5)$ & $142(23.1)$ & $77(12.5)$ & \\
\hline Age & & & & & $<0.001$ \\
\hline$<40$ & $30(17.5)$ & 34 (19.9) & $37(21.6)$ & $70(40.9)$ & \\
\hline $40-49$ & $54(19.6)$ & $57(20.7)$ & $84(30.4)$ & $81(29.4)$ & \\
\hline $50-59$ & $180(19.9)$ & $221(24.4)$ & $262(28.9)$ & $244(26.9)$ & \\
\hline $60-69$ & $317(27.7)$ & $295(25.8)$ & $261(22.8)$ & $271(23.7)$ & \\
\hline $70-$ & $190(32.6)$ & $163(28.0)$ & $126(21.6)$ & $104(17.8)$ & \\
\hline Smoking & & & & & $<0.001$ \\
\hline Non & $378(33.3)$ & $279(24.6)$ & $254(22.4)$ & $224(19.7)$ & \\
\hline Low-Modarate & $114(20.80)$ & $141(25.7)$ & $147(26.8)$ & $146(26.6)$ & \\
\hline High-Moderate & $137(21.5)$ & $169(26.6)$ & $163(25.6)$ & $167(26.3)$ & \\
\hline Heavy & $140(19.2)$ & $172(23.6)$ & $197(27.0)$ & $221(30.3)$ & \\
\hline Unknown & $2(6.3)$ & $9(28.1)$ & $9(28.1)$ & $12(37.5)$ & \\
\hline Alcohol consumption & & & & & 0.02 \\
\hline Non & $269(26.4)$ & $259(25.4)$ & $244(24.0)$ & $247(24.2)$ & \\
\hline Moderate & $219(25.8)$ & $196(23.1)$ & $207(24.4)$ & $226(26.7)$ & \\
\hline $1-2$ go $\times 5 /$ week & $191(26.9)$ & $185(26.0)$ & $171(24.1)$ & $164(23.1)$ & \\
\hline$>2$ go $\times 5 /$ week & $83(17.8)$ & $119(25.5)$ & $137(29.3)$ & $128(27.4)$ & \\
\hline Unknown & $9(25.0)$ & $11(30.6)$ & $11(30.6)$ & $5(13.9)$ & \\
\hline Flushing phenotype & & & & & 0.19 \\
\hline Yes & $383(24.6)$ & $383(24.6)$ & $377(24.2)$ & $412(26.5)$ & \\
\hline No & $363(25.0)$ & $368(25.3)$ & $378(26.0)$ & $346(23.8)$ & \\
\hline Unknown & $25(35.2)$ & $19(26.8)$ & $15(21.1)$ & $12(16.9)$ & \\
\hline Teeth & & & & & 0.62 \\
\hline 0 & $28(23.1)$ & $33(27.3)$ & $30(24.8)$ & $30(24.8)$ & \\
\hline $1-8$ & $93(24.9)$ & $98(26.2)$ & $81(21.7)$ & $102(27.3)$ & \\
\hline $9-20$ & $218(24.8)$ & $208(23.7)$ & $231(26.3)$ & $222(25.3)$ & \\
\hline$\geq 21$ & $424(25.3)$ & $427(25.5)$ & $419(25.0)$ & $403(24.1)$ & \\
\hline Unknown & $8(23.5)$ & $4(11.8)$ & $9(26.5)$ & $13(38.2)$ & \\
\hline Occupation group & & & & & $<0.001$ \\
\hline Blue collar & $143(17.0)$ & $191(22.7)$ & $230(27.4)$ & $277(32.9)$ & \\
\hline White collar & $198(21.6)$ & $241(26.3)$ & $234(25.5)$ & $244(26.6)$ & \\
\hline Other & $411(32.3)$ & $323(25.4)$ & $295(23.2)$ & $243(19.1)$ & \\
\hline Unknown & $19(37.3)$ & $15(29.4)$ & $11(21.6)$ & $6(11.8)$ & \\
\hline
\end{tabular}

and UATC risk were consistently observed. We explored alternative analyses using the DII computed with alcohol included and confirmed that results were consistent with those based on the DII not including alcohol (data not shown).

\section{DISCUSSION}

For the first time in a Japanese population, this case-control study examined the association between inflammatory potential of diet, as estimated by the 
Table 3: Impact of DII and selected variables

\begin{tabular}{|c|c|c|c|c|}
\hline & DII quartiles & Case/control & OR $(95 \% \text { CI })^{a}$ & Adjusted OR (95\% CI) \\
\hline \multicolumn{5}{|l|}{$\begin{array}{l}\text { Head and neck + } \\
\text { Esophagus }\end{array}$} \\
\hline & $1(-4.31--1.00)$ & $174 / 771$ & 1.00 (Reference) & 1.00 (Reference) \\
\hline & $2(-1.00--0.11)$ & $243 / 770$ & $1.41(1.13-1.76)$ & $1.33(1.04-1.69)$ \\
\hline & $3(0.11-0.58)$ & $278 / 770$ & $1.62(1.31-2.01)$ & $1.39(1.10-1.76)$ \\
\hline & $4(0.58-2.02)$ & $333 / 770$ & $1.96(1.58-2.43)$ & $1.73(1.37-2.20)$ \\
\hline & $P$ for trend & & $<0.001$ & $<0.001$ \\
\hline \multicolumn{5}{|l|}{ Head and neck } \\
\hline & $1(-4.08--1.13)$ & $96 / 443$ & 1.00 (Reference) & 1.00 (Reference) \\
\hline & $2(-1.13--0.12)$ & $129 / 447$ & $1.35(1.00-1.81)$ & $1.33(0.97-1.82)$ \\
\hline & $3(-0.12-0.52)$ & $168 / 449$ & $1.76(1.33-2.35)$ & $1.57(1.17-2.13)$ \\
\hline & $4(0.52-1.99)$ & $202 / 446$ & $2.16(1.63-2.87)$ & $1.92(1.42-2.59)$ \\
\hline & $P$ for trend & & $<0.001$ & $<0.001$ \\
\hline \multicolumn{5}{|l|}{ Esophagus } \\
\hline & $1(-4.31--1.03)$ & $78 / 328$ & 1.00 (Reference) & 1.00 (Reference) \\
\hline & $2(-1.03--0.11)$ & $114 / 323$ & $1.50(1.08-2.10)$ & $1.11(0.99-1.25)$ \\
\hline & $3(0.11-0.57)$ & $110 / 321$ & $1.45(1.04-2.02)$ & $1.42(1.29-1.57)$ \\
\hline & $4(0.57-2.02)$ & $131 / 324$ & $1.72(1.24-2.38)$ & $1.71(1.54-1.90)$ \\
\hline & $P$ for trend & & 0.003 & 0.07 \\
\hline
\end{tabular}

adds ratios were estimated by conditional logistic models not adjusted for any covariates.

${ }^{b}$ Odds ratios were estimated by conditional logistic models adjusted for smoking, ethanol consumption, flushing

phenotype, teeth and occupation group.

DII, and risk of UATC for the first time in a Japanese population. We found consistently significant positive associations with UATC risk even after accounting for potential confounders. Results were consistent among head and neck cancer and esophageal cancer. We also found that the strength of the association with DII scores was heterogeneous across subsites in head and neck cancer: nasopharyngeal and hypopharyngeal cancer showed increased risk at even in DII quartiles 2 and 3. In contrast, laryngeal cancer showed no obvious association with DII.

Our overall findings are in accordance with previous reports showing that a pro-inflammatory diet, as indicated by higher DII scores, was associated with UATC risk [2729, 42-44]. Our findings also are consistent with previous results showing that smoking and alcohol drinking are established risk factors for UATC and our finding is in consistent with former findings. Constituents in cigarette smoke constituents, particularly reactive oxidative substances (ROS), activate epithelial cell intracellular signaling cascades that lead to inflammatory gene activation (e.g., IL- 8 and TNF- $\alpha$ ), and the secretion of those inflammatory mediators promotes chronic immune cell recruitment and inflammation [45]. Similarly, chronic ethanol exposure also induces inflammation; ethanol toxicity is associated with the induction of NF- $\kappa B$ that results in the expression of inflammatory mediators including cytokines (TNF- $\alpha$, IL-6 and IL-12), lipid mediators, inducible nitric oxide synthase (iNOS) and cyclooxigenase-2 (COX-2) [46]. Therefore, a significantly positive association between DII and UATC risk seems biologically plausible.

Interestingly, we observed marked impact of even minor increases in DII scores in increasing hypopharyngeal and nasopharyngeal cancer risk. Both sites are known to be associated with infections by human papilloma virus (HPV) [47-50] and Epstein-Barr virus (EBV) [51, 52], respectively. Inflammation caused by chronic infection is regarded as a major risk factors for various types of cancer, and underlying infections and inflammation are linked to $15-20 \%$ of all cancer deaths [53]. Immune response to pathogens that establish persistent infections is designed to promote host defense; however, it also can stimulate chronic inflammation and tumor growth [54]. HPV infection produces and releases several inflammatory cytokines from keratinocytes, their main target cell type; from skin fibroblasts; and form different components of the innate and adaptive immune response, including macrophages, natural killer cells and lymphocytes. On the other hand, infection of EBV results in the activation of STAT3 and NF- $\kappa \mathrm{B}$ signal cascades in target epithelial cells, which induces increased 
Table 4: Imapct of DII according to detailed subsites in head and neck cancer

\begin{tabular}{|c|c|c|c|c|}
\hline \multicolumn{5}{|c|}{ Head and neck } \\
\hline Subsites & DII quartiles & Case/control & OR $(95 \% \mathrm{CI})^{\mathrm{a}}$ & $\begin{array}{c}\text { Adjusted OR } \\
(95 \% \mathrm{CI})^{\mathrm{b}}\end{array}$ \\
\hline \multirow[t]{5}{*}{ Oral cavity } & $1(-4.08--1.13)$ & $47 / 196$ & 1.00 (Reference) & 1.00 (Reference) \\
\hline & $2(-1.13--0.12)$ & $50 / 183$ & $1.17(0.74-1.84)$ & $1.21(0.75-1.96)$ \\
\hline & $3(-0.12-0.52)$ & $62 / 205$ & $1.32(0.86-2.03)$ & $1.25(0.79-1.96)$ \\
\hline & $4(0.52-1.99)$ & $96 / 178$ & $2.42(1.58-3.71)$ & $2.38(1.52-3.72)$ \\
\hline & $P$ for trend & & $<0.001$ & $<0.001$ \\
\hline \multirow[t]{5}{*}{ Nasopharynx } & $1(-4.08--1.13)$ & $4 / 37$ & 1.00 (Reference) & 1.00 (Reference) \\
\hline & $2(-1.13--0.12)$ & $12 / 36$ & $3.24(0.92-11.46)$ & $5.71(1.05-30.89)$ \\
\hline & $3(-0.12-0.52)$ & $17 / 35$ & $4.88(1.47-16.17)$ & $7.78(1.65-36.57)$ \\
\hline & $4(0.52-1.99)$ & $17 / 45$ & $3.65(1.10-12.11)$ & $4.99(1.14-21.79)$ \\
\hline & $P$ for trend & & 0.05 & 0.09 \\
\hline \multirow[t]{5}{*}{ Oropharynx } & $1(-4.08--1.13)$ & $12 / 56$ & 1.00 (Reference) & 1.00 (Reference) \\
\hline & $2(-1.13--0.12)$ & $18 / 52$ & $1.62(0.69-3.80)$ & $2.18(0.82-5.83)$ \\
\hline & $3(-0.12-0.52)$ & $22 / 49$ & $2.02(0.92-4.42)$ & $2.14(0.87-5.24)$ \\
\hline & $4(0.52-1.99)$ & $20 / 57$ & $1.63(0.72-3.69)$ & $1.71(0.65-4.50)$ \\
\hline & $P$ for trend & & 0.21 & 0.27 \\
\hline \multirow[t]{5}{*}{ Hypopharynx } & $1(-4.08--1.13)$ & $6 / 51$ & 1.00 (Reference) & 1.00 (Reference) \\
\hline & $2(-1.13--0.12)$ & $23 / 61$ & $3.29(1.24-8.71)$ & $4.39(1.36-14.11)$ \\
\hline & $3(-0.12-0.52)$ & $29 / 65$ & $4.18(1.55-11.26)$ & $4.59(1.45-14.51)$ \\
\hline & $4(0.52-1.99)$ & $22 / 63$ & $3.03(1.15-7.97)$ & $4.05(1.24-13.25)$ \\
\hline & $P$ for trend & & 0.07 & 0.04 \\
\hline \multirow[t]{5}{*}{ Larynx } & $1(-4.08--1.13)$ & $18 / 56$ & 1.00 (Reference) & 1.00 (Reference) \\
\hline & $2(-1.13--0.12)$ & $15 / 78$ & $0.63(0.30-1.33)$ & $0.39(0.16-0.99)$ \\
\hline & $3(-0.12-0.52)$ & $30 / 62$ & $1.53(0.77-3.06)$ & $1.02(0.43-2.44)$ \\
\hline & $4(0.52-1.99)$ & $29 / 79$ & $1.17(0.59-2.33)$ & $0.59(0.25-1.38)$ \\
\hline & $P$ for trend & & 0.21 & 0.68 \\
\hline \multirow[t]{5}{*}{ Salivary gland } & $1(-4.08--1.13)$ & $5 / 23$ & 1.00 (Reference) & 1.00 (Reference) \\
\hline & $2(-1.13--0.12)$ & $6 / 21$ & $1.35(0.38-4.88)$ & $1.57(0.37-6.63)$ \\
\hline & $3(-0.12-0.52)$ & $4 / 15$ & $1.41(0.32-6.16)$ & $1.07(0.19-5.97)$ \\
\hline & $4(0.52-1.99)$ & $8 / 13$ & $5.42(1.01-29.17)$ & $2.91(0.40-21.19)$ \\
\hline & $P$ for trend & & 0.08 & 0.13 \\
\hline
\end{tabular}

${ }^{a}$ Odds ratios were estimated by conditional logistic models not adjusted for any covariates.

${ }^{b}$ Odds ratios were estimated by conditional logistic models adjusted for smoking, ethanol

consumption, flushing phenotype, teeth and occupation group.

expression of inflammatory cytokines including IL-6 and COX-2 [55]. Persistent infections with these viruses have been linked to chronic inflammation, an important factor for cancer development [56]. Taking these facts into consideration, our finding suggests that the proinflammatory potential of diet, as indicated by higher DII scores, significantly increases risk of infection-related cancers.
Previous reports revealed protective effect of vegetable, fruits [57, 58], olive oil [59], fish [29, 60], whole grains $[61,62]$, vitamin $[63,64]$, folate $[65,66]$ and fiber $[63,67]$; whereas there appears to be a carcinogenic effect of red and processed meat [68, 69], fat $[58,70]$ and carbohydrate $[71,72]$ for UATC. These foods and nutrients, all components of DII, have the potential to induce the inflammatory response by 
Table 5: Results for stratified analysis by selected variables

\begin{tabular}{|c|c|c|c|c|c|c|c|}
\hline \multicolumn{8}{|c|}{ Head and neck + Esophagus } \\
\hline \multicolumn{8}{|c|}{ DII quartiles } \\
\hline \multirow[b]{2}{*}{ Variables } & & $1(-4.31--1.00)$ & $2(-1.00-0.11)$ & $3(0.11-0.58)$ & \multirow[t]{2}{*}{$4(0.58-2.02)$} & & \\
\hline & \multicolumn{4}{|c|}{$\begin{array}{c}\text { Case/control }(n) \\
\text { Multivariate OR }(95 \% \text { CI })\end{array}$} & & $P$ for trend & $\begin{array}{c}\text { interaction } \\
\boldsymbol{P}^{b}\end{array}$ \\
\hline \multirow[t]{4}{*}{ Sex } & Male & $134 / 538$ & $192 / 607$ & $225 / 628$ & $275 / 693$ & 0.012 & \\
\hline & & $\begin{array}{l}1.00 \text { (Reference) } \\
1.17(0.88-1.55)\end{array}$ & $1.21(0.92-1.59)$ & $1.41(1.08-1.85)$ & & & \\
\hline & Female & $40 / 233$ & $51 / 163$ & $53 / 142$ & $58 / 77$ & $<0.001$ & $<0.001$ \\
\hline & & $\begin{array}{l}1.00 \text { (Reference) } \\
1.88(1.13-3.13)\end{array}$ & $1.91(1.15-3.15)$ & $3.87(2.22-6.75)$ & & & \\
\hline \multirow[t]{4}{*}{ Age } & $<60$ & $61 / 264$ & $89 / 312$ & $113 / 383$ & $188 / 395$ & 0.001 & \\
\hline & & $\begin{array}{l}1.00 \text { (Reference) } \\
1.07(0.71-1.61)\end{array}$ & $1.16(0.78-1.72)$ & $1.78(1.22-2.60)$ & & & \\
\hline & $\geq 60$ & $113 / 507$ & $154 / 458$ & $165 / 387$ & $145 / 375$ & 0.006 & 0.18 \\
\hline & & $\begin{array}{l}1.00 \text { (Reference) } \\
1.52(1.11-2.08)\end{array}$ & $1.67(1.22-2.28)$ & $1.54(1.12-2.14)$ & & & \\
\hline \multirow[t]{4}{*}{ Smoking } & Never & $45 / 378$ & $48 / 279$ & $45 / 254$ & $63 / 224$ & $<0.001$ & \\
\hline & & $\begin{array}{l}1.00 \text { (Reference) } \\
1.74(0.98-3.08)\end{array}$ & $1.91(1.08-3.36)$ & $3.03(1.65-5.55)$ & & & \\
\hline & Ever & $129 / 393$ & $194 / 490$ & $233 / 516$ & $269 / 543$ & 0.007 & 0.021 \\
\hline & & 1.00 (Reference) & $1.22(0.90-1.66)$ & $1.37(1.03-1.84)$ & $1.48(1.10-1.98)$ & & \\
\hline \multirow{4}{*}{$\begin{array}{l}\text { Alcohol } \\
\text { consumption }\end{array}$} & Never & $37 / 26941 / 259$ & $58 / 244$ & $63 / 247$ & $<0.001$ & & \\
\hline & & 1.00 (Reference) & $1.14(0.61-2.13)$ & $1.85(1.02-3.34)$ & $3.21(1.68-6.14)$ & & \\
\hline & Ever & $137 / 502$ & $201 / 510$ & $220 / 526$ & $270 / 523$ & 0.003 & 0.58 \\
\hline & & 1.00 (Reference) & $1.25(0.93-1.68)$ & $1.17(0.88-1.56)$ & $1.59(1.20-2.12)$ & & \\
\hline \multirow{4}{*}{$\begin{array}{l}\text { Flushing } \\
\text { phenotype }\end{array}$} & Yes & $79 / 383$ & $97 / 383$ & $124 / 377$ & $143 / 412$ & 0.040 & \\
\hline & & 1.00 (Reference) & $1.09(0.69-1.72)$ & $1.56(1.01-2.42)$ & $1.46(0.93-2.30)$ & & \\
\hline & No & $88 / 363$ & $137 / 368$ & $140 / 378$ & $179 / 346$ & 0.005 & 0.67 \\
\hline & & 1.00 (Reference) & $1.49(0.96-2.32)$ & $1.05(0.67-1.64)$ & $2.05(1.34-3.13)$ & & \\
\hline \multirow[t]{6}{*}{ Teeth } & $0-8$ & $48 / 121$ & $77 / 131$ & $65 / 111$ & $88 / 132$ & 0.540 & \\
\hline & & 1.00 (Reference) & $2.11(0.88-5.05)$ & $1.40(0.57-3.44)$ & $1.62(0.62-4.25)$ & & \\
\hline & $9-20$ & $58 / 218$ & $68 / 208$ & $89 / 231$ & $94 / 222$ & 0.460 & 0.49 \\
\hline & & 1.00 (Reference) & $0.87(0.45-1.68)$ & $1.00(0.54-1.88)$ & $1.22(0.65-2.29)$ & & \\
\hline & $\geq 21$ & $68 / 424$ & $96 / 427$ & $118 / 419$ & $145 / 403$ & 0.002 & \\
\hline & & 1.00 (Reference) & $1.20(0.77-1.88)$ & $1.44(0.94-2.20)$ & $1.86(1.22-2.85)$ & & \\
\hline \multirow{6}{*}{$\begin{array}{l}\text { Occupation } \\
\text { group }\end{array}$} & Blue collar & $56 / 143$ & $89 / 191$ & $99 / 230$ & $137 / 277$ & 0.410 & \\
\hline & & 1.00 (Reference) & $0.79(0.39-1.59)$ & $0.80(0.41-1.54)$ & $1.18(0.61-2.26)$ & & \\
\hline & White collar & $38 / 198$ & $40 / 241$ & $62 / 234$ & $77 / 244$ & 0.080 & $<0.001$ \\
\hline & & 1.00 (Reference) & $0.91(0.39-2.13)$ & $1.15(0.54-2.48)$ & $1.78(0.82-3.86)$ & & \\
\hline & Other & $78 / 411$ & $112 / 323$ & $113 / 295$ & $114 / 243$ & 0.005 & \\
\hline & & 1.00 (Reference) & $1.70(1.11-2.60)$ & $1.61(1.06-2.46)$ & $1.97(1.27-3.08)$ & & \\
\hline
\end{tabular}

${ }^{a}$ Odds ratios were estimated by conditional logistic models adjusted for smoking, ethanol consumption, flushing, phenotype, teeth and occupation group. bInteractions were evaluated by likelihood ratio test between a model including a cross-product term between variables of interest and DII quartiles and a model without the term.

influencing inflammatory markers such as CRP, IL-1 $\beta$, IL-4, IL-6, IL-10 and TNF- $\alpha$ [12, 13, 73]. Particularly, CRP, IL-6 and TNF- $\alpha$, in particular, have been reported to be associated with a variety of cancers [74-78]. Cyclooxygenase pathway products with the potential to influence inflammation include reactive oxygen species (ROS) and nitric oxide (NO). These can damage DNA and other cellular macromolecules. This damage results in increased proliferation, mutations, DNA damage and angiogenesis $[75,79,80]$. Among inflammatory markers, 
IL-1 $\beta$ has been demonstrated to induce the production of gelatinases, which are family members of the matrix metalloproteinases (MMPs) that contribute to tumor invasion and metastasis [81], whereas IL-4 and IL-10 play a role in immune suppression, and IL-6 plays a role in anti-apoptosis [74] for head and neck cancer.

The methodological strengths of this study include its large sample size with very high $(96.7 \%)$ response rate. Second, the FFQ that provided the data for DII estimation was tested for validity and reproducibility [39, 82]. Third, potential confounding by age, sex and other factors was addressed by matching and statistical adjustment.

Despite its strengths, potential limitations of our study also warrant mention. First, we collected information about confounders via self-reported questionnaire, therefore, it is difficult to rule out potential sources of information bias. If present, however, the effect of such misclassification in relation to possible under-adjustment would be limited. Also consistency of results across stratified analysis by several potential confounders is reassuring. Second, the control participants were selected among non-cancer patients at our hospital. Because cases and controls were selected from the same hospital and almost all patients lived in the Tokai area of central Japan, the internal validity of this case-control study is likely to be acceptable [83].

Third, by not setting eligibility criteria for control diseases it is possible that certain specific diagnostic groups may be related exposures of interest. Fourth, the limited number of cases for particular subsites reduces statistical power. Fifth, because of the retrospective nature of data collection, information bias in responses to the FFQ cannot be ruled out. Sixth, no validation study on the DII has been conducted in Japan. However, the DII was designed for universal applicability and has been construct validated in numerous populations including Asian countries such as Korea [84] and Iran [85]. All of these validation studies produced essentially identical results. Seventh, 22 food parameters were not-available to calculate DII scores. Previously, we showed that DII scores calculated from fewer than 22 food parameters were associated with inflammation [86]. Some of the food parameters that are missing include ginger, turmeric, saffron, thyme, eugenol - all of which are not consumed in high amounts in this population. However, presence of some missing parameters, such as various flavonoids, which are consumed regularly, could have influenced the results.

In conclusion, we found a positive association between intake of a pro-inflammatory diet, as indicated by high DII score, and risk of UATC in Japanese adults. Results persisted after adjusting for potential confounders, including smoking and drinking. The association was consistently observed in esophageal cancer and most of UATC subsites, except laryngeal cancer. The fact that subsites which are known to have an etiological association with persistent infection; i.e., nasopharyngeal and hypopharyngeal cancers, showed stronger associations. These results warrant further evaluation in future studies.

\section{MATERIALS AND METHODS}

\section{Subjects}

This case-control study includes 1,028 incident UATC cases and 3,081 age- and sex-matched controls. Both cases and controls were selected from participants of the Hospitalbased Epidemiologic Research Program at Aichi Cancer Center (HERPACC) between January 2001 and November 2005 at Aichi Cancer Center Hospital (ACCH) in Japan. Detail of HERPACC is described elsewhere [37]. Briefly, all first-visit outpatients $(n=29,736)$ during the study period were asked to complete self-administered questionnaire and provide blood samples. Of these, $28,776(96.7 \%)$ agreed to participate and provided written informed consent. Of these, 14,329 subjects were not diagnosed as having cancer within the 1-year period before determining study eligibility. Among the remaining 14,447 subjects, 9,838 were diagnosed with incident cancer of any organ, 3,657 were prevalent cases and 952 were of undetermined status. Cases were selected from 9,838 incident cancer cases and controls from 14,329 participants who were determined not to have cancer.

Cases in this study were participants of HERPACC who were histologically diagnosed as having a newly incident UATC [cancer of head and neck in $595(57.9 \%)$, cancer of esophagus in 433 (42.1\%)] without any prior history of cancer. We defined UATC according to the following codes of the International Classification of Diseases and Related Health Problems (ICD10): cancers of the oral cavity and oropharynx (C00.3-C00.9, C01, C02.0-C02.4, C03, C04, C05.0-C05.2, C06, C09 and C10), hypopharynx (C12 and $\mathrm{C} 13)$, oral cavity-oropharynxhypopharynx if not otherwise specified (C02.8, C02.9, C05.8, C05.9 and C14), salivary glands (C07 and C08), nasopharynx (C11), larynx (C32) and esophagus (C15). Head and neck cancer was defined as UATC other than esophageal cancer. All subsites of UATC were frequencymatched on age and sex at a case-control ratio of 1:3.

Control subjects also were participants of HERPACC during the same period, but were confirmed to have no detectable cancer and no history of neoplasia. Non-cancer status was confirmed by medical examinations, including radiographic examinations when indicated. We applied individual matching for control selection on age ( \pm 4 years)- and sex. They were selected randomly from non-cancer subjects among HERPACC participants in a case-control ratio of 1:3. The study was approved by the Institutional Ethics Committee at ACC.

\section{Data collection}

Information on potential confounders, alcohol consumption, cumulative exposure to smoking, 
socioeconomic status (SES), number of teeth and flushing response after drinking of a glass of beer was collected using a self-administered questionnaire.

We grouped cumulative exposure to smoking status into four categories by pack-years (PY) as follows: nonsmoker, low-moderate smoker $(\mathrm{PY}<20)$, highmoderate smoker $(20 \leq \mathrm{PY}<40)$, and heavy smoker (PY $\geq 40$ ). Daily alcohol consumption of various common beverages (Japanese sake, beer, shochu, whiskey and wine) was determined according to the average number of drinks per day, which was then converted into a Japanese sake (rice wine) equivalent measure of 180 $\mathrm{ml}$; termed a go, which is a standard measure in Japan containing $23 \mathrm{~g}$ of ethanol. Drinking status in this study was classified into the four categories of never drinker, moderate drinker (less than 1 go on 5 days per week), high-moderate drinkers (1-2 go on 5 days per week) and heavy drinkers (more than 2 go on 5 days per week).

The intake of nutrients was measured using a semiquantitative food frequency questionnaire (FFQ), described in detail elsewhere [38]. Briefly, the FFQ consisted of 47 single food items with eight frequency categories and three portion size categories (small, medium, and large) provided. We estimated average daily intake by multiplying the reported frequency of intake by the selected serving size of each food (g). Intakes of all food items were not-energyadjusted. The FFQ was validated in a population similar to that of our study using a 3-day weighed dietary record as the reference standard; results indicated acceptable reproducibility and validity [39].

Participants also were asked about their occupation as a measure of SES and were categorized into three groups as follows: white collar, blue collar or others, including part-time employees, housewives, students, unemployed, retired and inactive. Number of teeth of participants were categorized into four groups as follows: $0,1-8,9-20,>21$. Flushing response after drinking of a glass of beer was categorized as yes or no.

\section{Dietary inflammatory index}

Dietary inflammatory index $\left(\mathrm{DII}^{\circledR}\right)$ scores were estimated based on self-reported macro- and micronutrients (energy, protein, fat, carbohydrate, total dietary fiber, cholesterol, saturated fatty acid, monounsaturated fatty acid, polyunsaturated fatty acid, n-3 polyunsaturated fatty acid, n-6 polyunsaturated fatty acid, carotene, vitamin B1, vitamin B2, vitamin B6, vitamin $\mathrm{B} 12$, vitamin $\mathrm{C}$, vitamin $\mathrm{D}$, vitamin $\mathrm{E}$, retinoic acid, folate, and iron) based on the FFQ, described in detail elsewhere [38]. Briefly, dietary data were first linked to a regionally representative global database that provided a robust estimate of the mean and the standard deviation for each food parameter included in the DII. These parameters then became the multipliers to express an individual's exposure relative to the "standard global mean" as a z-score. This was achieved by subtracting the "standard global mean" from the amount reported and dividing this value by the standard deviation. To minimize the effect of "right skewing," this value was then converted to a centered (on zero) proportion by converting the $\mathrm{z}$-score to a proportion (i.e., with values from 0 to 1 ) then multiplying by 2 and subtracting 1 . The centered proportion score for each food parameter for each subject was then multiplied by the corresponding food parameter effect score in order to obtain a food parameter-specific DII score. All of the food parameter-specific DII scores were then summed to create the overall DII score for each subject. Alcohol was not included in the DII calculation, as it was adjusted separately in the analyses. The remaining 23 food parameters that were not used or were missing are mentioned in Supplementary Table 1.

\section{Statistical analyses}

We evaluated the association between DII and UATC risk using quartiles of DII scores. Quartile thresholds for DII were based on the distribution of DII in matched controls. Odds ratios (ORs) and 95\% confidence intervals (CI) were estimated using conditional logistic regression models, with the first DII quartile (Q1, most anti-inflammatory diet category) as the reference. In the logistic regression model, the linear association with DII was evaluated by including DII quartile as an ordinal score $(1,2,3$, and 4). Potential confounders considered in the adjusted analyses were smoking, alcohol consumption, flushing phenotype [40], number of teeth [41] and occupational group. We also examined the impact of DII according to anatomic subtypes of UATC. The impact of DII was evaluated with stratification by the abovementioned confounders in UATC. Interactions were evaluated by the likelihood ratio test comparing a model including a cross-product term between variables of interest and DII quartiles and a model without the term.

Chi-square tests for categorical variables and ANOVA for continuous variables were used to assess difference across groups. Statistical analyses were performed using STATA $^{\circledR}$ SE version 13.1 (Stata Corporation, College Station, TX,

USA). $P$-Values less than 0.05 were considered significant.

\section{ACKNOWLEDGMENTS AND FUNDING}

This study was supported by Grants-in-Aid for Scientific Research on Priority Areas from the Ministry of Education, Science, Sports, Culture and Technology of Japan (17015018 and 26860430), JSPS Kakenhi (18K10037), and a Grant-in-Aid for the Third Term Comprehensive 10-year Strategy for Cancer Control from 
the Ministry of Health, Labour and Welfare of Japan; and the National Cancer Center Research and Development Fund. (27-A-4).

Drs. Shivappa and Hébert were supported by grant number R44DK103377 from the United States National Institute of Diabetes and Digestive and Kidney Diseases.

NS, JRH, and KM contributed conception, design of the work. MA, NS, and KM conducted analyses. HI, IO, TA, YA, YH, NS, JRH and KM contributed to acquisition of data in the work. MA, NS, HI, IO, TA, YA, YH, CK, $\mathrm{MN}, \mathrm{YO}, \mathrm{JRH}$ and $\mathrm{KM}$ contributed to interpretation of data in the work. All authors participated in drafting and revising the manuscript and approved the version submitted. Each author accepts accountability for all aspects of the work.

\section{CONFLICTS OF INTEREST}

Dr. James R. Hébert owns controlling interest in Connecting Health Innovations LLC (CHI), a company planning to license the right to his invention of the dietary inflammatory index (DII) from the University of South Carolina in order to develop computer and smart phone applications for patient counselling and dietary intervention in clinical settings. Dr. Nitin Shivappa is an employee of CHI.

\section{REFERENCES}

1. Ferlay J, Soerjomataram I, Ervik M, Dikshit R, Eser S, Mathers C, Rebelo M, Parkin D, Forman D, Bray F. (2013). GLOBOCAN 2012 v1.0, Cancer Incidence and Mortality Worldwide: IARC CancerBase No. 11.

2. La Vecchia C, Tavani A, Franceschi S, Levi F, Corrao G, Negri E. Epidemiology and prevention of oral cancer. Oral Oncol. 1997; 33:302-12.

3. Bagnardi V, Blangiardo M, La Vecchia C, Corrao G. A metaanalysis of alcohol drinking and cancer risk. Br J Cancer. 2001; 85:1700-5. https://doi.org/10.1054/bjoc.2001.2140.

4. Li Y, Mao Y, Zhang Y, Cai S, Chen G, Ding Y, Guo J, Chen K, Jin M. Alcohol drinking and upper aerodigestive tract cancer mortality: a systematic review and metaanalysis. Oral Oncol. 2014; 50:269-75. https://doi. org/10.1016/j.oraloncology.2013.12.015.

5. Boyle P, Levin B. Head and neck cancers. World Cancer Report 2008. Lyon, France:World Health Organization. International Agency for Research on Cancer. 2008; 330-337.

6. Boyle P, Levin B. Esophageal cancer. World Cancer Report 2008. Lyon, France:World Health Organization. International Agency for Research on Cancer. 2008; 338-343.

7. Edefonti V, Bravi F, La Vecchia C, Randi G, Ferraroni M, Garavello W, Franceschi S, Talamini R, Boffetta P, Decarli A. Nutrient-based dietary patterns and the risk of oral and pharyngeal cancer. Oral Oncol. 2010; 46:343-8. https://doi.org/10.1016/j.oraloncology.2009.11.017.

8. Chainani-Wu N. Diet and oral, pharyngeal, and esophageal cancer. Nutr Cancer. 2002; 44:104-26. https://doi. org/10.1207/s15327914nc4402_01.

9. De Stefani E, Boffetta P, Ronco AL, Correa P, Oreggia F, Deneo-Pellegrini H, Mendilaharsu M, Leiva J. Dietary patterns and risk of cancer of the oral cavity and pharynx in Uruguay. Nutr Cancer. 2005; 51:132-9. https://doi. org/10.1207/s15327914nc5102_2.

10. World Cancer Research Fund / American Institute for Cancer Research. Food, Nutrition, Physical Acitivity, and the Prevention of Cancer: a Global Perspective. Washington DC: AICR, 2007.

11. Ricordi C, Garcia-Contreras M, Farnetti S. Diet and Inflammation: Possible Effects on Immunity, Chronic Diseases, and Life Span. J Am Coll Nutr. 2015; 34:10-3. https://doi.org/10.1080/07315724.2015.1080101.

12. Nettleton JA, Steffen LM, Mayer-Davis EJ, Jenny NS, Jiang R, Herrington DM, Jacobs DR Jr. Dietary patterns are associated with biochemical markers of inflammation and endothelial activation in the Multi-Ethnic Study of Atherosclerosis (MESA). Am J Clin Nutr. 2006; 83:1369-79.

13. Esmaillzadeh A, Kimiagar M, Mehrabi Y, Azadbakht L, $\mathrm{Hu}$ FB, Willett WC. Dietary patterns and markers of systemic inflammation among Iranian women. J Nutr. 2007; 137:992-8.

14. Shivappa N, Steck SE, Hurley TG, Hussey JR, Ma Y, Ockene IS, Tabung F, Hebert JR. A population-based dietary inflammatory index predicts levels of C-reactive protein in the Seasonal Variation of Blood Cholesterol Study (SEASONS). Public Health Nutr. 2014; 17:1825-33. https://doi.org/10.1017/s1368980013002565.

15. Libby P. Inflammatory mechanisms: the molecular basis of inflammation and disease. Nutr Rev. 2007; 65:S140-6.

16. Pearson TA, Mensah GA, Alexander RW, Anderson JL, Cannon RO 3rd, Criqui M, Fadl YY, Fortmann SP, Hong Y, Myers GL, Rifai N, Smith SC Jr, Taubert K, et al. Markers of inflammation and cardiovascular disease: application to clinical and public health practice: A statement for healthcare professionals from the Centers for Disease Control and Prevention and the American Heart Association. Circulation. 2003; 107:499-511.

17. Bastard JP, Jardel C, Bruckert E, Blondy P, Capeau J, Laville M, Vidal H, Hainque B. Elevated levels of interleukin 6 are reduced in serum and subcutaneous adipose tissue of obese women after weight loss. J Clin Endocrinol Metab. 2000; 85:3338-42. https://doi. org/10.1210/jcem.85.9.6839.

18. Festa A, D'Agostino R Jr, Howard G, Mykkanen L, Tracy RP, Haffner SM. Chronic subclinical inflammation as part of the insulin resistance syndrome: the Insulin Resistance Atherosclerosis Study (IRAS). Circulation. $2000 ; 102: 42-7$. 
19. Hansson GK. Inflammation, atherosclerosis, and coronary artery disease. N Engl J Med. 2005; 352:1685-95. https:// doi.org/10.1056/NEJMra043430.

20. Ahluwalia N, Andreeva VA, Kesse-Guyot E, Hercberg S. Dietary patterns, inflammation and the metabolic syndrome. Diabetes Metab. 2013; 39:99-110. https://doi.org/10.1016/j. diabet.2012.08.007.

21. Bonomi M, Patsias A, Posner M, Sikora A. The role of inflammation in head and neck cancer. Adv Exp Med Biol. 2014; 816:107-27. https://doi. org/10.1007/978-3-0348-0837-8_5.

22. Baniyash M, Sade-Feldman M, Kanterman J. Chronic inflammation and cancer: suppressing the suppressors. Cancer Immunol Immunother. 2014; 63:11-20. https://doi. org/10.1007/s00262-013-1468-9.

23. Groblewska M, Mroczko B, Sosnowska D, Szmitkowski M. Interleukin 6 and C-reactive protein in esophageal cancer. Clin Chim Acta. 2012; 413:1583-90. https://doi. org/10.1016/j.cca.2012.05.009.

24. Blank S, Nienhuser H, Dreikhausen L, Sisic L, Heger U, Ott K, Schmidt T. Inflammatory cytokines are associated with response and prognosis in patients with esophageal cancer. Oncotarget. 2017; 8:47518-47532. https://doi. org/10.18632/oncotarget.17671.

25. Shivappa N, Steck SE, Hurley TG, Hussey JR, Hebert JR. Designing and developing a literature-derived, populationbased dietary inflammatory index. Public Health Nutr. 2014; 17:1689-96. https://doi.org/10.1017/s1368980013002115.

26. Tabung FK, Steck SE, Zhang J, Ma Y, Liese AD, Agalliu I, Hingle M, Hou L, Hurley TG, Jiao L, Martin LW, Millen AE, Park HL, et al. Construct validation of the dietary inflammatory index among postmenopausal women. Ann Epidemiol. 2015; 25:398-405. https://doi. org/10.1016/j.annepidem.2015.03.009.

27. Shivappa N, Zucchetto A, Serraino D, Rossi M, La Vecchia C, Hebert JR. Dietary inflammatory index and risk of esophageal squamous cell cancer in a case-control study from Italy. Cancer Causes Control. 2015; 26:1439-47. https://doi.org/10.1007/s10552-015-0636-y.

28. Shivappa N, Hebert JR, Rosato V, Serraino D, La Vecchia C. Inflammatory potential of diet and risk of laryngeal cancer in a case-control study from Italy. Cancer Causes Control. 2016; 27:1027-34. https://doi.org/10.1007/ s10552-016-0781-y.

29. Shivappa N, Hebert JR, Rosato V, Garavello W, Serraino D, La Vecchia C. Inflammatory potential of diet and risk of oral and pharyngeal cancer in a large case-control study from Italy. Int J Cancer. 2017; 141:471-9. https://doi. org/10.1002/ijc.30711.

30. Shivappa N, Zucchetto A, Montella M, Serraino D, Steck SE, La Vecchia C, Hebert JR. Inflammatory potential of diet and risk of colorectal cancer: a case-control study from Italy. Br J Nutr. 2015; 114:152-8. https://doi. org/10.1017/s0007114515001828.
31. Shivappa N, Bosetti C, Zucchetto A, Montella M, Serraino D, La Vecchia C, Hebert JR. Association between dietary inflammatory index and prostate cancer among Italian men. Br J Nutr. 2015; 113:278-83. https://doi. org/10.1017/s0007114514003572.

32. Shivappa N, Bosetti C, Zucchetto A, Serraino D, La Vecchia C, Hebert JR. Dietary inflammatory index and risk of pancreatic cancer in an Italian case-control study. Br J Nutr. 2015; 113:292-8. https://doi.org/10.1017/ s0007114514003626.

33. Shivappa N, Hebert JR, Zucchetto A, Montella M, Serraino D, La Vecchia C, Rossi M. Dietary inflammatory index and endometrial cancer risk in an Italian case-control study. Br J Nutr. 2016; 115:138-46. https://doi.org/10.1017/ s0007114515004171.

34. Shivappa N, Hebert JR, Polesel J, Zucchetto A, Crispo A, Montella M, Franceschi S, Rossi M, La Vecchia C, Serraino D. Inflammatory potential of diet and risk for hepatocellular cancer in a case-control study from Italy. Br J Nutr. 2016; 115:324-31. https://doi.org/10.1017/ s0007114515004419.

35. Shivappa N, Blair CK, Prizment AE, Jacobs DR Jr, Steck SE, Hebert JR. Association between inflammatory potential of diet and mortality in the Iowa Women's Health study. Eur J Nutr. 2016; 55:1491-502. https://doi. org/10.1007/s00394-015-0967-1.

36. Tabung FK, Steck SE, Ma Y, Liese AD, Zhang J, Caan B, Hou L, Johnson KC, Mossavar-Rahmani Y, Shivappa N, Wactawski-Wende J, Ockene JK, Hebert JR. The association between dietary inflammatory index and risk of colorectal cancer among postmenopausal women: results from the Women's Health Initiative. Cancer Causes Control. 2015; 26:399-408. https://doi.org/10.1007/s10552-014-0515-y.

37. Hamajima N, Matsuo K, Saito T, Hirose K, Inoue M, Takezaki T, Kuroishi T, Tajima K. Gene-environment Interactions and Polymorphism Studies of Cancer Risk in the Hospital-based Epidemiologic Research Program at Aichi Cancer Center II (HERPACC-II). Asian Pac J Cancer Prev. 2001; 2:99-107.

38. Tokudome S, Goto C, Imaeda N, Tokudome Y, Ikeda M, Maki S. Development of a data-based short food frequency questionnaire for assessing nutrient intake by middle-aged Japanese. Asian Pac J Cancer Prev. 2004; 5:40-3.

39. Tokudome Y, Goto C, Imaeda N, Hasegawa T, Kato R, Hirose K, Tajima K, Tokudome S. Relative validity of a short food frequency questionnaire for assessing nutrient intake versus three-day weighed diet records in middle-aged Japanese. J Epidemiol. 2005; 15:135-45.

40. Yokoyama A, Yokoyama T, Omori T. Past and current tendency for facial flushing after a small dose of alcohol is a marker for increased risk of upper aerodigestive tract cancer in Japanese drinkers. Cancer Sci. 2010; 101:2497-8; author reply 9-500. https://doi. org/10.1111/j.1349-7006.2010.01709.x. 
41. Hiraki A, Matsuo K, Suzuki T, Kawase T, Tajima K. Teeth loss and risk of cancer at 14 common sites in Japanese. Cancer Epidemiol Biomarkers Prev. 2008; 17:1222-7. https://doi.org/10.1158/1055-9965.epi-07-2761.

42. Shivappa N, Hebert JR, Rosato V, Garavello W, Serraino D, La Vecchia C. Inflammatory potential of diet and risk of oral and pharyngeal cancer in a large case-control study from Italy. Int J Cancer. 2017; 141:471-479. https://doi. org/10.1002/ijc.30711.

43. Shivappa N, Hebert JR, Rashidkhani B. Dietary Inflammatory Index and Risk of Esophageal Squamous Cell Cancer in a Case-Control Study from Iran. Nutr Cancer. 2015; 67:1253-9. https://doi.org/10.1080/01635581.2015. 1082108 .

44. Lu Y, Shivappa N, Lin Y, Lagergren J, Hebert JR. Diet-related inflammation and oesophageal cancer by histological type: a nationwide case-control study in Sweden. Eur J Nutr. 2016; 55:1683-94. https://doi. org/10.1007/s00394-015-0987-x.

45. Churg A, Dai J, Tai H, Xie C, Wright JL. Tumor necrosis factor-alpha is central to acute cigarette smoke-induced inflammation and connective tissue breakdown. Am J Respir Crit Care Med. 2002; 166:849-54. https://doi. org/10.1164/rccm.200202-097OC.

46. Iimuro Y, Gallucci RM, Luster MI, Kono H, Thurman RG. Antibodies to tumor necrosis factor alfa attenuate hepatic necrosis and inflammation caused by chronic exposure to ethanol in the rat. Hepatology. 1997; 26:1530-7. https://doi. org/10.1002/hep.510260621.

47. zur Hausen H. Papillomaviruses and cancer: from basic studies to clinical application. Nat Rev Cancer. 2002; 2:342-50. https://doi.org/10.1038/nrc798.

48. Mork J, Lie AK, Glattre E, Hallmans G, Jellum E, Koskela P, Moller B, Pukkala E, Schiller JT, Youngman L, Lehtinen M, Dillner J. Human papillomavirus infection as a risk factor for squamous-cell carcinoma of the head and neck. N Engl J Med. 2001; 344:1125-31. https://doi. org/10.1056/nejm200104123441503.

49. Smith EM, Ritchie JM, Summersgill KF, Klussmann JP, Lee JH, Wang D, Haugen TH, Turek LP. Age, sexual behavior and human papillomavirus infection in oral cavity and oropharyngeal cancers. Int J Cancer. 2004; 108:766-72. https://doi.org/10.1002/ijc.11633.

50. Kreimer AR, Johansson M, Waterboer T, Kaaks R, ChangClaude J, Drogen D, Tjonneland A, Overvad K, Quiros JR, Gonzalez CA, Sanchez MJ, Larranaga N, Navarro C, et al. Evaluation of human papillomavirus antibodies and risk of subsequent head and neck cancer. J Clin Oncol. 2013; 31:2708-15. https://doi.org/10.1200/jco.2012.47.2738.

51. Raab-Traub N, Flynn K. The structure of the termini of the Epstein-Barr virus as a marker of clonal cellular proliferation. Cell. 1986; 47:883-9.

52. Pagano JS, Blaser M, Buendia MA, Damania B, Khalili K, Raab-Traub N, Roizman B. Infectious agents and cancer: criteria for a causal relation. Semin Cancer Biol. 2004; 14:453-71. https://doi.org/10.1016/j.semcancer.2004.06.009.

53. Kuper H, Adami HO, Trichopoulos D. Infections as a major preventable cause of human cancer. J Intern Med. 2000; 248:171-83.

54. Kuraishy A, Karin M, Grivennikov SI. Tumor promotion via injury- and death-induced inflammation. Immunity. 2011; 35:467-77. https://doi.org/10.1016/j.immuni.2011.09.006.

55. Lo AK, Lo KW, Tsao SW, Wong HL, Hui JW, To KF, Hayward DS, Chui YL, Lau YL, Takada K, Huang DP. Epstein-Barr virus infection alters cellular signal cascades in human nasopharyngeal epithelial cells. Neoplasia. 2006; 8:173-80. https://doi.org/10.1593/neo.05625.

56. Balkwill F, Mantovani A. Inflammation and cancer: back to Virchow? Lancet. 2001; 357:539-45. https://doi. org/10.1016/s0140-6736(00)04046-0.

57. Bosetti C, La Vecchia C, Talamini R, Simonato L, Zambon P, Negri E, Trichopoulos D, Lagiou P, Bardini R, Franceschi S. Food groups and risk of squamous cell esophageal cancer in northern Italy. Int J Cancer. 2000; 87:289-94.

58. Bravi F, Bosetti C, Filomeno M, Levi F, Garavello W, Galimberti S, Negri E, La Vecchia C. Foods, nutrients and the risk of oral and pharyngeal cancer. Br J Cancer. 2013; 109:2904-10. https://doi.org/10.1038/bjc.2013.667.

59. Pelucchi C, Bosetti C, Negri E, Lipworth L, La Vecchia C. Olive oil and cancer risk: an update of epidemiological findings through 2010. Curr Pharm Des. 2011; 17:805-12.

60. Salehi M, Moradi-Lakeh M, Salehi MH, Nojomi M, Kolahdooz F. Meat, fish, and esophageal cancer risk: a systematic review and dose-response meta-analysis. Nutr Rev. 2013; 71:257-67. https://doi.org/10.1111/nure.12028.

61. Jessri M, Rashidkhani B, Hajizadeh B, Jacques PF. Adherence to Mediterranean-style dietary pattern and risk of esophageal squamous cell carcinoma: a case-control study in Iran. J Am Coll Nutr. 2012; 31:338-51.

62. Arthur AE, Peterson KE, Rozek LS, Taylor JM, Light E, Chepeha DB, Hebert JR, Terrell JE, Wolf GT, Duffy SA. Pretreatment dietary patterns, weight status, and head and neck squamous cell carcinoma prognosis. Am J Clin Nutr. 2013; 97:360-8. https://doi.org/10.3945/ajcn.112.044859.

63. Kubo A, Corley DA, Jensen CD, Kaur R. Dietary factors and the risks of oesophageal adenocarcinoma and Barrett's oesophagus. Nutr Res Rev. 2010; 23:230-46. https://doi. org/10.1017/s0954422410000132.

64. Edefonti V, Hashibe M, Parpinel M, Ferraroni M, Turati F, Serraino D, Matsuo K, Olshan AF, Zevallos JP, Winn DM, Moysich K, Zhang ZF, Morgenstern H, et al. Vitamin E intake from natural sources and head and neck cancer risk: a pooled analysis in the International Head and Neck Cancer Epidemiology consortium. Br J Cancer. 2015; 113:182-92. https://doi.org/10.1038/bjc.2015.149. 
65. Pelucchi C, Talamini R, Negri E, Levi F, Conti E, Franceschi S, La Vecchia C. Folate intake and risk of oral and pharyngeal cancer. Ann Oncol. 2003; 14:1677-81.

66. Pelucchi C, Talamini R, Levi F, Bosetti C, La Vecchia C, Negri E, Parpinel M, Franceschi S. Fibre intake and laryngeal cancer risk. Ann Oncol. 2003; 14:162-7.

67. Bidoli E, Pelucchi C, Polesel J, Negri E, Barzan L, Franchin G, Franceschi S, Serraino D, De Paoli P, La Vecchia C, Talamini R. Fiber intake and risk of nasopharyngeal carcinoma: a case-control study. Nutr Cancer. 2013; 65:1157-63. https://doi.org/10.1080/01635581.2013.82 8088 .

68. Qu X, Ben Q, Jiang Y. Consumption of red and processed meat and risk for esophageal squamous cell carcinoma based on a meta-analysis. Ann Epidemiol. 2013; 23:762-70. e1. https://doi.org/10.1016/j.annepidem.2013.09.003.

69. Oreggia F, De Stefani E, Boffetta P, Brennan P, DeneoPellegrini H, Ronco AL. Meat, fat and risk of laryngeal cancer: a case-control study in Uruguay. Oral Oncol. 2001; $37: 141-5$.

70. O'Doherty MG, Cantwell MM, Murray LJ, Anderson LA, Abnet CC. Dietary fat and meat intakes and risk of reflux esophagitis, Barrett's esophagus and esophageal adenocarcinoma. Int J Cancer. 2011; 129:1493-502. https:// doi.org/10.1002/ijc.26108.

71. Eslamian G, Jessri M, Hajizadeh B, Ibiebele TI, Rashidkhani B. Higher glycemic index and glycemic load diet is associated with increased risk of esophageal squamous cell carcinoma: a case-control study. Nutr Res. 2013; 33:719 25. https://doi.org/10.1016/j.nutres.2013.06.002.

72. Augustin LS, Gallus S, Franceschi S, Negri E, Jenkins DJ, Kendall CW, Dal Maso L, Talamini R, La Vecchia C. Glycemic index and load and risk of upper aero-digestive tract neoplasms (Italy). Cancer Causes Control. 2003; 14:657-62.

73. Cavicchia PP, Steck SE, Hurley TG, Hussey JR, Ma Y, Ockene IS, Hebert JR. A new dietary inflammatory index predicts interval changes in serum high-sensitivity C-reactive protein. J Nutr. 2009; 139:2365-72. https://doi. org/10.3945/jn.109.114025.

74. Pries R, Wollenberg B. Cytokines in head and neck cancer. Cytokine Growth Factor Rev. 2006; 17:141-6. https://doi. org/10.1016/j.cytogfr.2006.02.001.

75. Hardikar S, Onstad L, Song X, Wilson AM, Montine TJ, Kratz M, Anderson GL, Blount PL, Reid BJ, White E, Vaughan TL. Inflammation and oxidative stress markers and esophageal adenocarcinoma incidence in a Barrett's esophagus cohort. Cancer Epidemiol Biomarkers Prev. 2014; 23:2393-403. https://doi.org/10.1158/1055-9965. epi-14-0384.

76. Allin KH, Bojesen SE, Nordestgaard BG. Baseline C-reactive protein is associated with incident cancer and survival in patients with cancer. J Clin Oncol. 2009; 27:2217-24. https://doi.org/10.1200/jco.2008.19.8440.

77. Il'yasova D, Colbert LH, Harris TB, Newman AB, Bauer DC, Satterfield S, Kritchevsky SB. Circulating levels of inflammatory markers and cancer risk in the health aging and body composition cohort. Cancer Epidemiol Biomarkers Prev. 2005; 14:2413-8. https://doi. org/10.1158/1055-9965.epi-05-0316.

78. Pine SR, Mechanic LE, Enewold L, Chaturvedi AK, Katki HA, Zheng YL, Bowman ED, Engels EA, Caporaso NE, Harris CC. Increased levels of circulating interleukin 6, interleukin 8, C-reactive protein, and risk of lung cancer. J Natl Cancer Inst. 2011; 103:1112-22. https://doi.org/10.1093/ jnci/djr216.

79. Coussens LM, Werb Z. Inflammation and cancer. Nature. 2002; 420:860-7. https://doi.org/10.1038/nature01322.

80. Ulrich CM, Bigler J, Potter JD. Non-steroidal antiinflammatory drugs for cancer prevention: promise, perils and pharmacogenetics. Nat Rev Cancer. 2006; 6:130-40. https://doi.org/10.1038/nrc1801.

81. Mann EA, Hibbs MS, Spiro JD, Bowik C, Wang XZ, Clawson $\mathrm{M}$, Chen LL. Cytokine regulation of gelatinase production by head and neck squamous cell carcinoma: the role of tumor necrosis factor-alpha. Ann Otol Rhinol Laryngol. 1995; 104:203-9. https://doi. org/10.1177/000348949510400305.

82. Willett W. Implications of total energy intake for epidemiologic analyses, Chapter 11. Nutritional epidemiology, 2nd edn. New York: Oxford University Press. 1998; p. 273-301.

83. Inoue M, Tajima K, Hirose K, Hamajima N, Takezaki T, Kuroishi T, Tominaga S. Epidemiological features of first-visit outpatients in Japan: comparison with general population and variation by sex, age, and season. J Clin Epidemiol. 1997; 50:69-77.

84. Na W, Kim M, Sohn C. Dietary inflammatory index and its relationship with high-sensitivity C-reactive protein in Korean: data from the health examinee cohort. J Clin Biochem Nutr. 2018; 62:83-8.

85. Vahid F, Shivappa N, Hekmatdoost A, Hebert JR, Davoodi SH, Sadeghi M. Association between Maternal Dietary Inflammatory Index (DII) and abortion in Iranian women and validation of DII with serum concentration of inflammatory factors: case-control study. Appl Physiol Nutr Metab. 2017; 42:511-6. https://doi.org/10.1139/ apnm-2016-0274.

86. Shivappa N, Hebert JR, Rietzschel ER, De Buyzere ML, Langlois M, Debruyne E, Marcos A, Huybrechts I. Associations between dietary inflammatory index and inflammatory markers in the Asklepios Study. Br J Nutr. 2015; 113:665-71. https://doi.org/10.1017/ s000711451400395x. 